\title{
Analysis of the Recovered Artifacts from the Controlled Surface Collection at the Peach Orchard Site (41CE477), Cherokee County, Texas
}

Timothy K. Perttula

Heritage Research Center, Stephen F. Austin State University

Kevin Stingley

Texas Archeological Stewardship Network, Texas Historical Commission

Follow this and additional works at: https://scholarworks.sfasu.edu/ita

Part of the American Material Culture Commons, Archaeological Anthropology Commons, Environmental Studies Commons, Other American Studies Commons, Other Arts and Humanities Commons, Other History of Art, Architecture, and Archaeology Commons, and the United States History Commons

Tell us how this article helped you.

This Article is brought to you for free and open access by the Center for Regional Heritage Research at SFA ScholarWorks. It has been accepted for inclusion in Index of Texas Archaeology: Open Access Gray Literature from the Lone Star State by an authorized editor of SFA ScholarWorks. For more information, please contact cdsscholarworks@sfasu.edu. 
Analysis of the Recovered Artifacts from the Controlled Surface Collection at the Peach Orchard Site (41CE477), Cherokee County, Texas

\section{Creative Commons License}

\section{(c) (1) (8)}

This work is licensed under a Creative Commons Attribution-NonCommercial 4.0 International License 


\title{
Analysis of the Recovered Artifacts from the Controlled Surface Collection at the Peach Orchard Site (41CE477), Cherokee County, Texas
}

\author{
Timothy K. Perttula and Kevin Stingley
}

\section{Introduction}

The Peach Orchard site is one of several historic Caddo archaeological sites recently recorded by Kevin Stingley in the Bowles Creek drainage in the middle Neches River basin in Cherokee County, Texas (Perttula et al. 2016:Figure 1). The Peach Orchard site had been exposed in erosion along a county road that bisects the southern end of the upland landform, while the remainder of the landform was primarily grass-covered when it was first recorded earlier in 2015. In November 2015, the landowner decided to shallowly plow the site area to improve its grass cover, and this plowing provided an opportunity to complete a surface collection of the site area from November to December 2015.

\section{Initial Artifact Assemblage Collected from the Peach Orchard Site}

A small surface collection at the Peach Orchard site had 71 ceramic sherds, mostly from utility ware jars (Perttula et al. 2016:Table 9). Sherds from plain ware and fine ware vessels only comprised 22.5 percent of the assemblage. The small ceramic sherd assemblage from the site was almost entirely from grog-tempered vessels ( 95.8 percent), especially including the utility wares. Bone-tempered sherds were most common in the plain wares and the fine wares.

Two of the fine ware sherds were from Patton Engraved vessels with either excised triangular or linear tick marks (Perttula et al. 2016:Figure 9). The other fine wares have simple opposed or straight line elements. More than 94 percent of the utility ware sherds from the site had brushed decorative elements, including horizontal brushing marks on the rim of utility ware jars and opposed, overlapping, and vertical brushing marks on the vessel body (Perttula et al. 2016:Table 11). One rim had a row of tool punctations below the vessel lip that had been pushed through the brushing. One of the utility ware sherds was from a Lindsey Grooved vessel, and two others had either incised or incised-punctated decorative elements.

The small sherd collection from the Peach Orchard site had a very low plain to decorated sherd ratio (0.18), and many brushed sherds compared to plain ware sherds (4.73:1). There also were not many other wet paste sherds in the ceramic assemblage from the site compared to sherds from brushed vessels, based on the brushed to other wet paste sherd ratio of 13.0.

Finally, there was one blue shell-edged whiteware rim sherd in the collection from the site. It had an even or regular scalloped rim with straight impressed lines. Such vessels were produced between ca. 1800 and 1840 (Hunter and Miller 2009:13), suggesting it may be associated with an early $19^{\text {th }}$ century use or occupation of the site, either by a Caddo Indian group, or an early Anglo-American settler.

\section{Controlled Surface Collection and Distribution of Recovered Artifacts}

After the site area and the larger field had been plowed (Figure 1) and rained on several times, a grid of $2110 \times 10$ m units (numbered 1-21) was laid out over the known surface spatial distribution of 
ancestral Caddo ceramic sherds (Figures 2 and 3); the extent of buried archaeological deposits has not yet been ascertained, but at least one shovel test will be excavated within each of the $10 \mathrm{x} 10 \mathrm{~m}$ units. The grid is oriented north-south (6 degrees), with a datum point in the southeast corner of the grid.

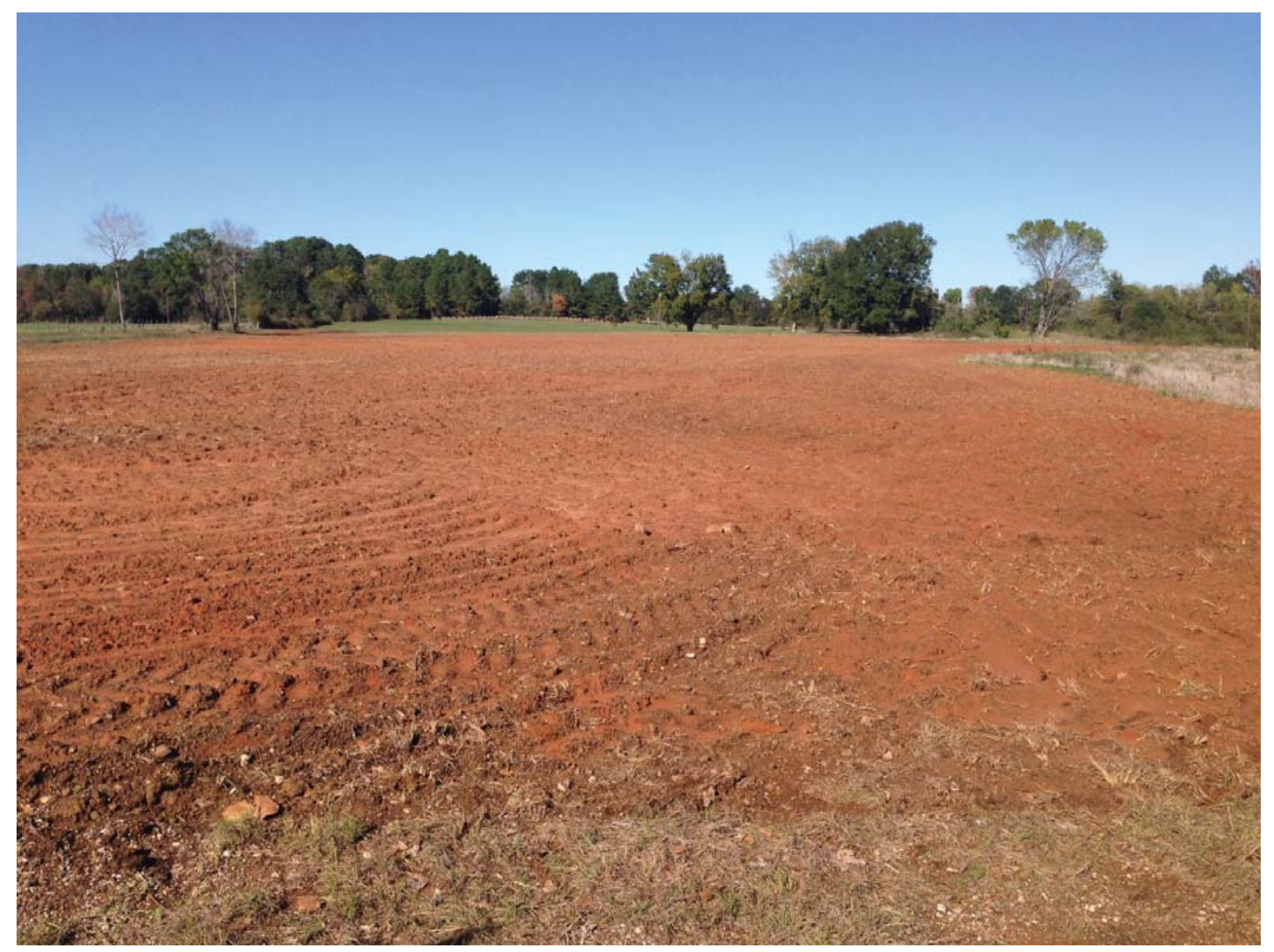

Figure 1. Looking north at the freshly-plowed field at the Peach Orchard site.

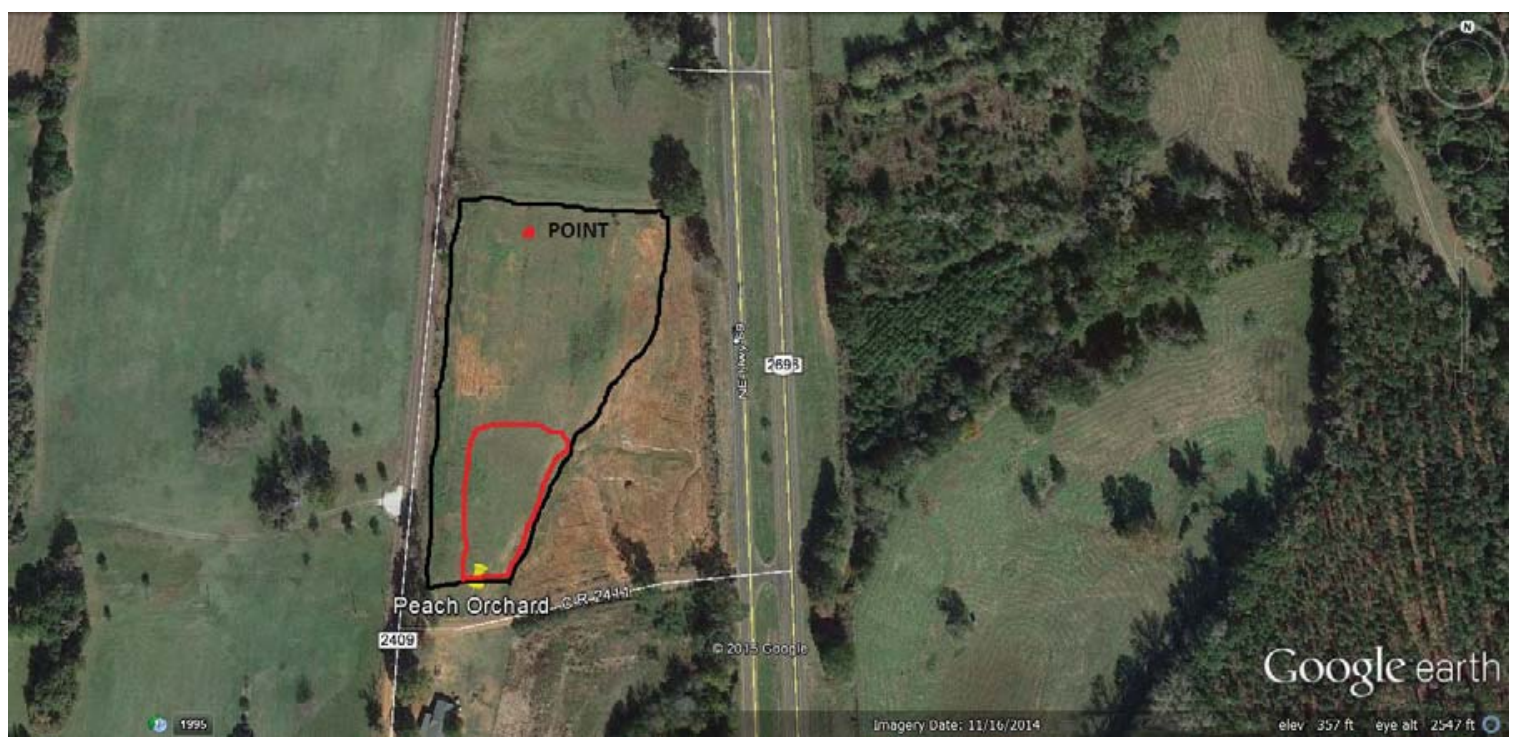

Figure 2. Caddo ceramic sherd area in the plowed field at the Peach Orchard site. 


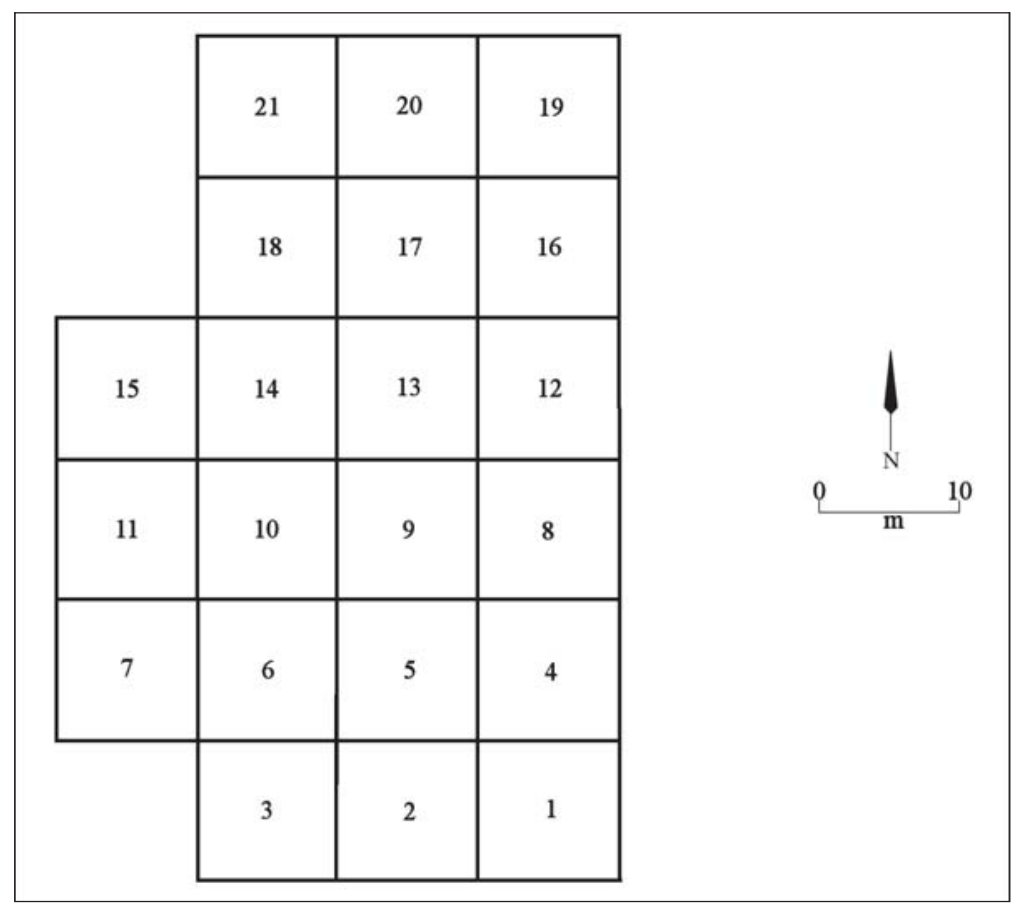

Figure 3. Grid of $10 \times 10$ m units in the controlled surface collection at the Peach Orchard site.

Based on the distribution of the major categories (i.e., total sherds, and distribution of utility ware and fine ware sherds) of ancestral Caddo artifacts across the site, the core area with the highest density of all categories of Caddo artifacts is in a 700 square meter area in the central and eastern part of the surface collection grid (Figure 4). The density of all ceramic vessel sherds ranges from 52-197 per 10 x $10 \mathrm{~m}$ unit (Figure 5), with a mean density of 100.0 sherds per collection unit, and a mean density of 1.0 sherd per square meter across the collected grid.

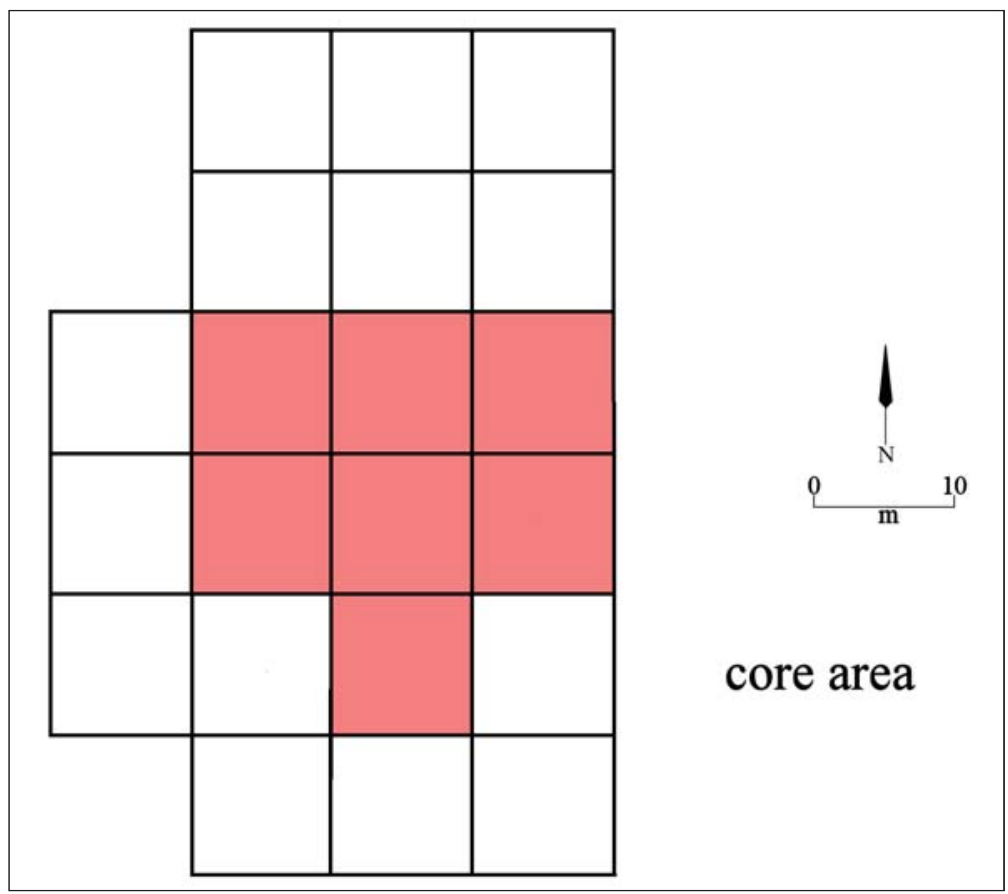

Figure 4. Core area of the Peach Orchard site based on the density of artifacts across the surface collection grid. 


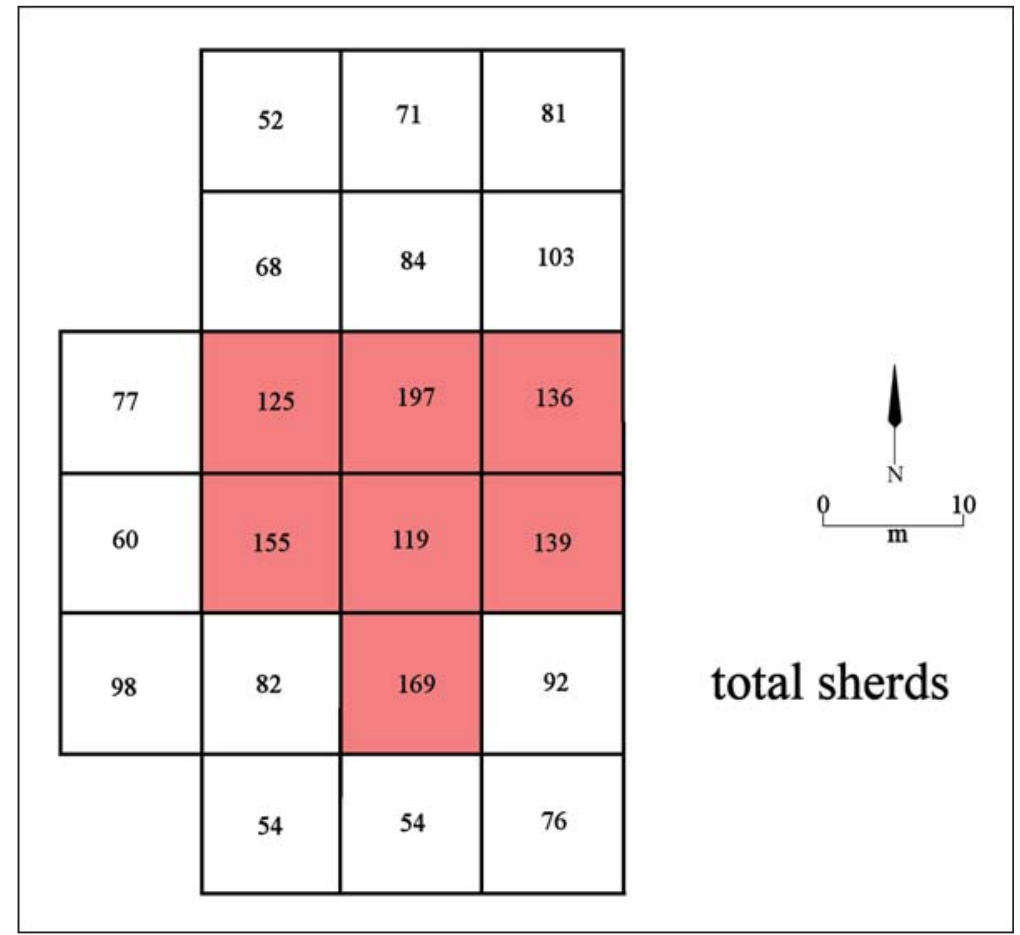

Figure 5. Density of total sherds in each 10 x 10 m collection unit.

Fine ware (i.e., engraved and trailed) sherds $(n=129)$ in the assemblage range from 1-17 sherds per surface collection unit (Figure 6), with a mean of 6.1 sherds per collection unit. Patton Engraved sherds are widespread across the surface collection grid (Figure 7).

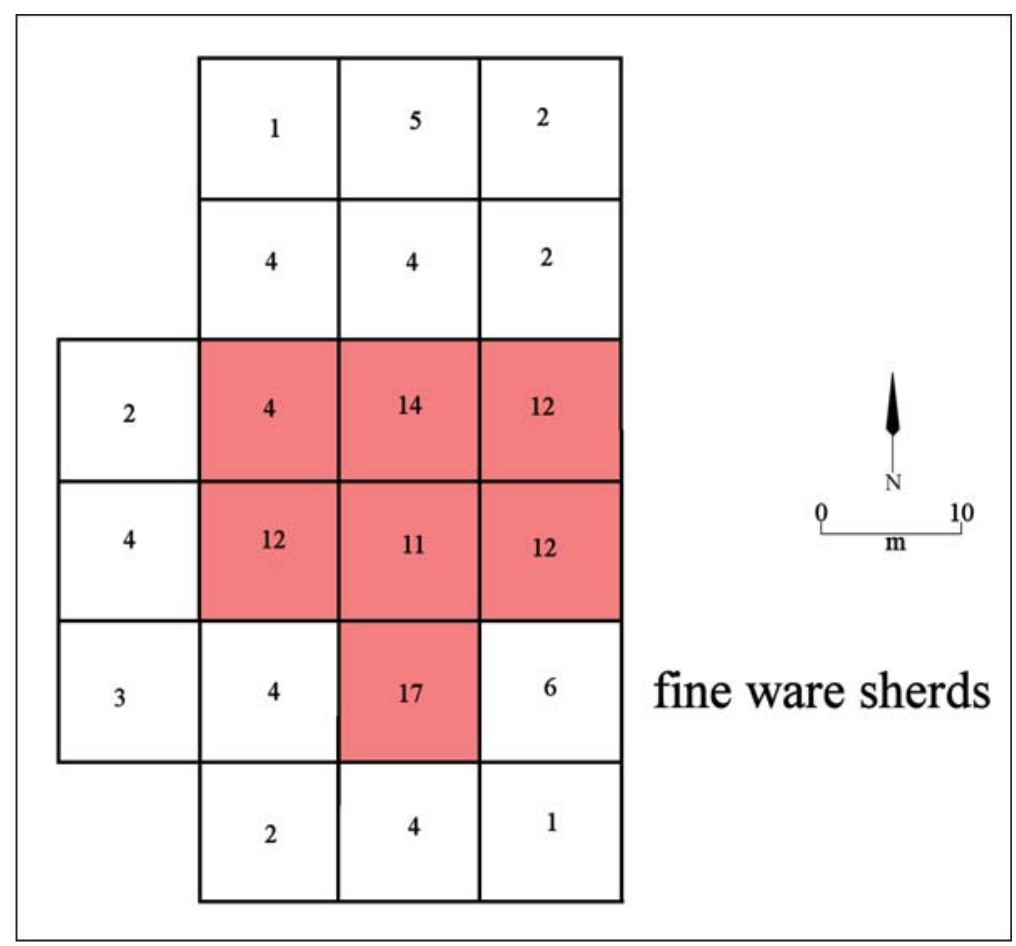

Figure 6 . Density of fine ware sherds in each 10 x 10 m collection unit. 


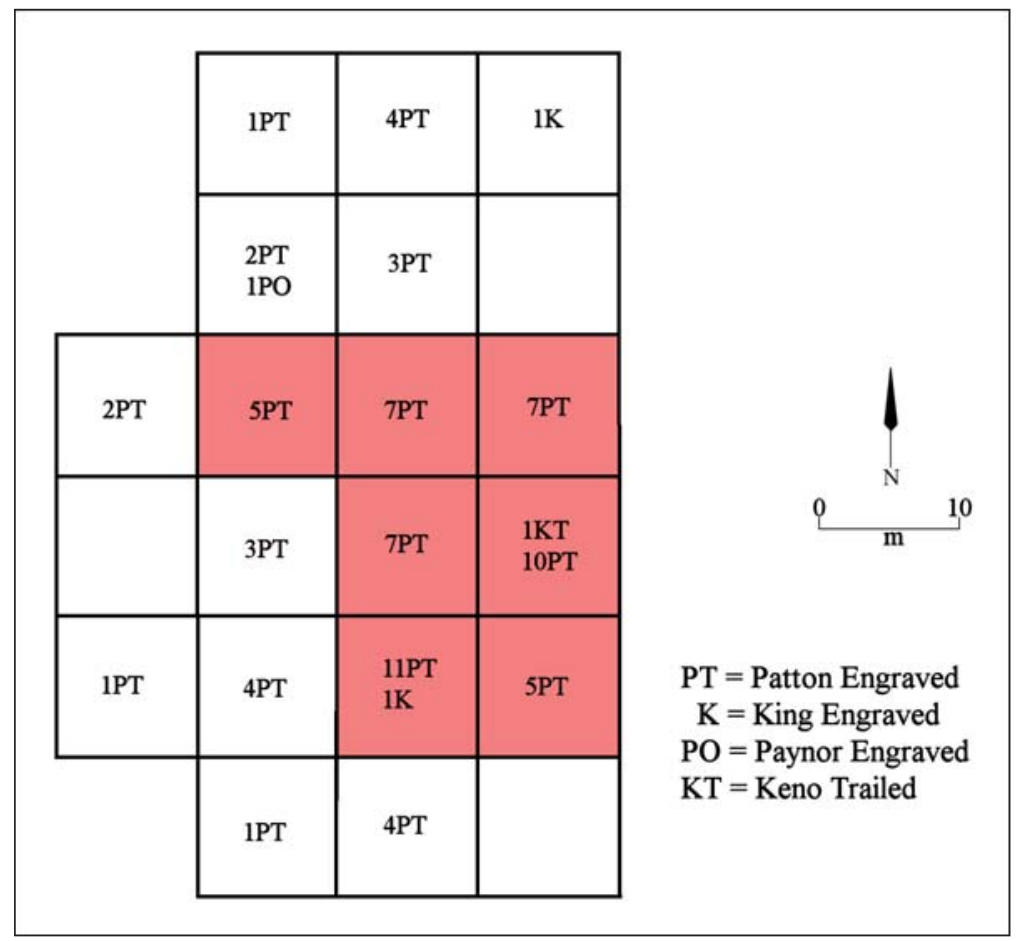

Figure 7. Distribution of specific fine ware ceramic types in each $10 \times 10$ m collection grid.

The density of utility ware sherds $(n=1367)$ ranges from 24-128 sherds per surface collection unit (Figure 8), with a mean of 65.1 sherds per collection unit. Specific utility wares such as Spradley Brushed-Incised, Lindsey Grooved, La Rue Neck Banded, and Maydelle Incised are concentrated in the central and southern parts of the surface collection grid (Figure 9), over a 1500 square meter area.

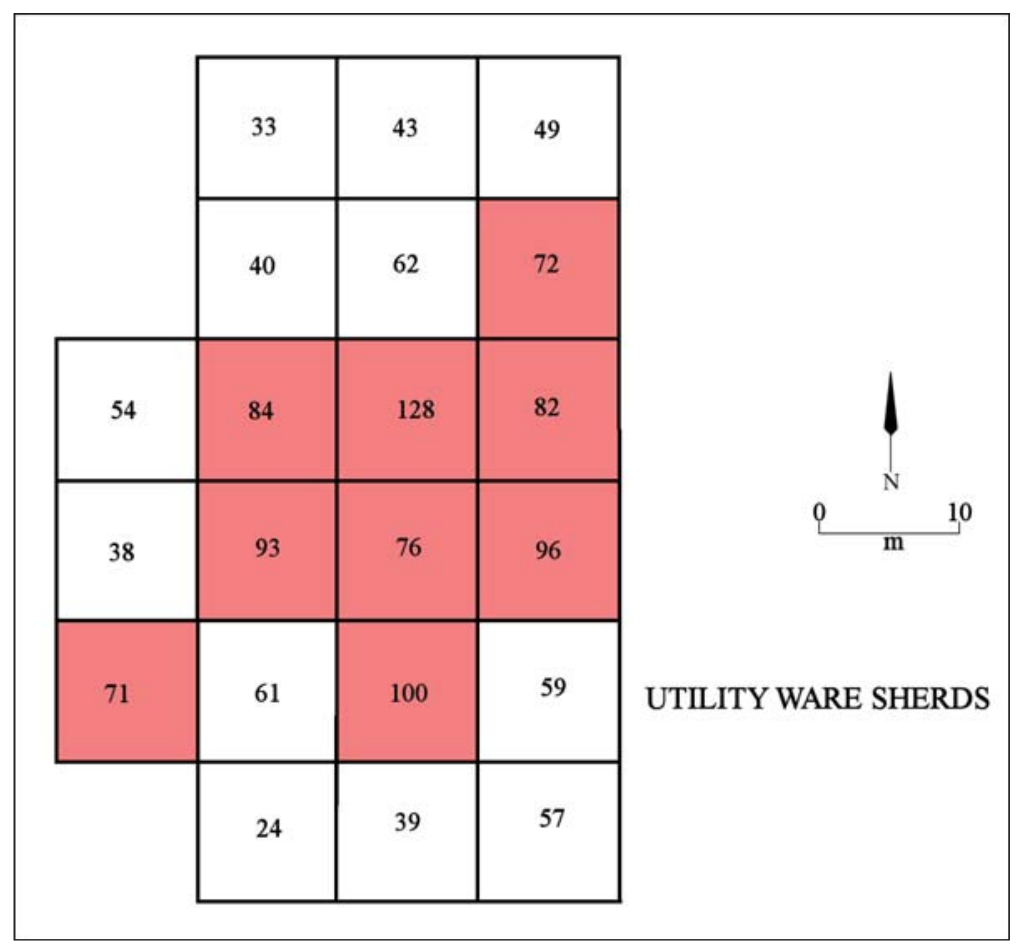

Figure 8 . Density of utility ware sherds in each $10 \times 10$ m collection unit. 


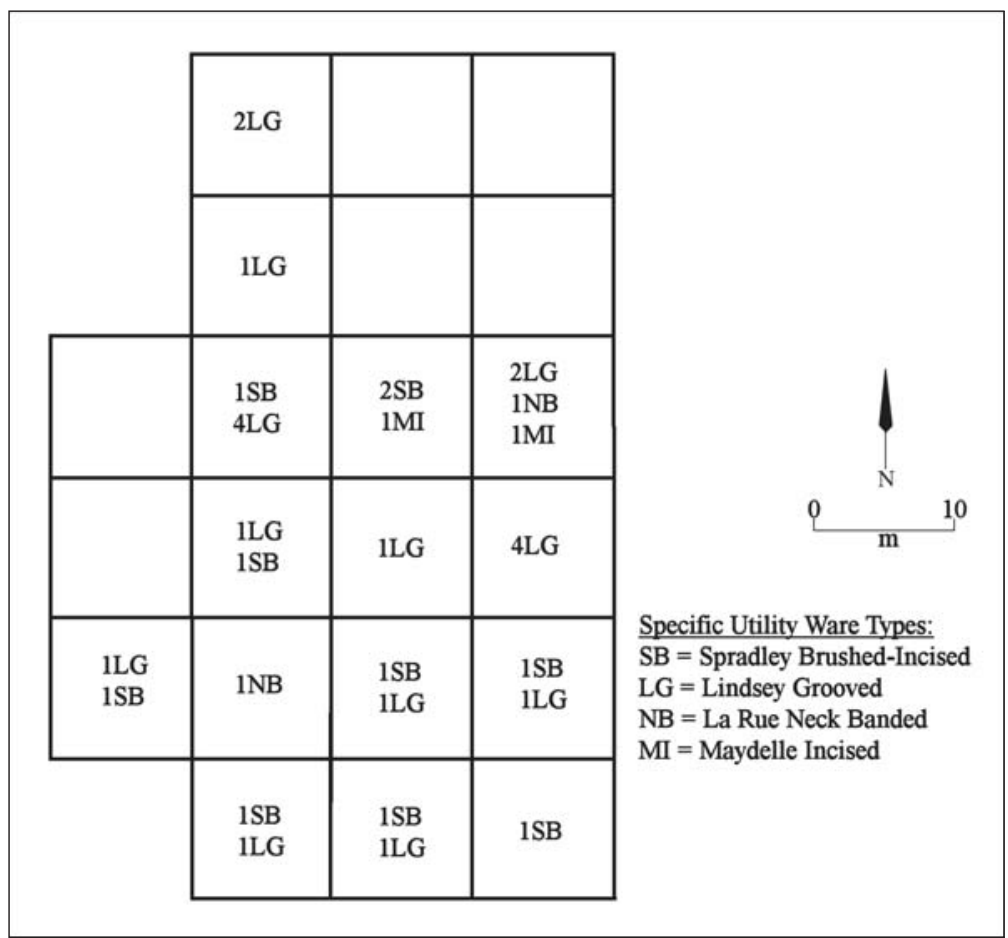

Figure 9. Distribution of specific utility ware ceramic types in each $10 \times 10 \mathrm{~m}$ collection grid.

Two ceramic elbow pipe sherds and a fired clay coil fragment were found in two $10 \times 10 \mathrm{~m}$ units (Figure 10) within the core artifact density area of the surface collection grid (see Figure 4). It is suspected that these artifacts were discarded within or very near an ancestral Caddo house structure at the Peach Orchard site. The two pieces of burned clay occur in two $10 \times 10 \mathrm{~m}$ units in the northern part of the grid (Figure 10).

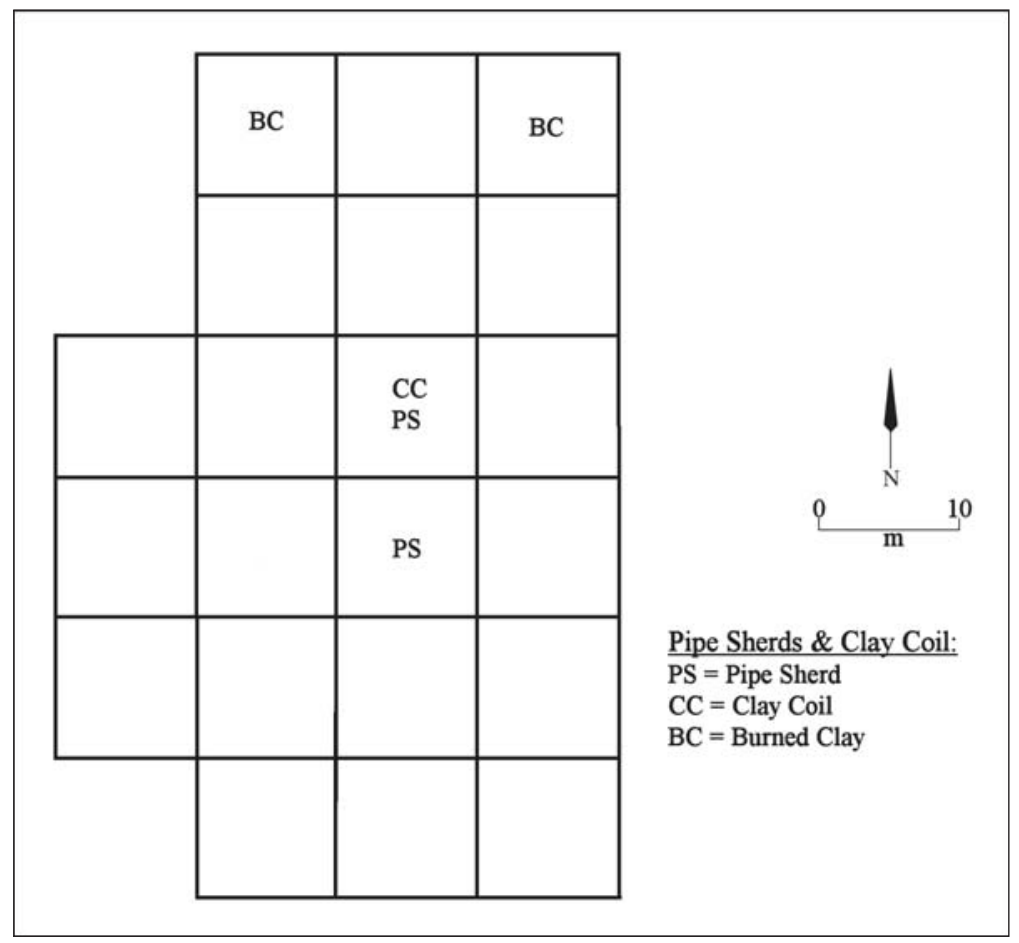

Figure 10. Distribution of ceramic elbow pipe sherds, burned clay, and a fired clay coil in the surface collection grid. 
A total of 12 chipped stone tools were recovered in the surface collection units at the Peach Orchard site (Figure 11). More than 83 percent of these tools come from the core artifact density of the surface collection grid (see Figure 4). In addition to one core and one ferruginous sandstone fire-cracked rock, 66 pieces of lithic debris were recovered in the surface collection (Figure 12), with a range of 1-12 pieces per unit; the mean density of the lithic debris is 3.1 pieces per $10 \times 10 \mathrm{~m}$ unit. About 68 percent of the lithic debris are from the core artifact density area of the surface collection grid (see Figure 4).

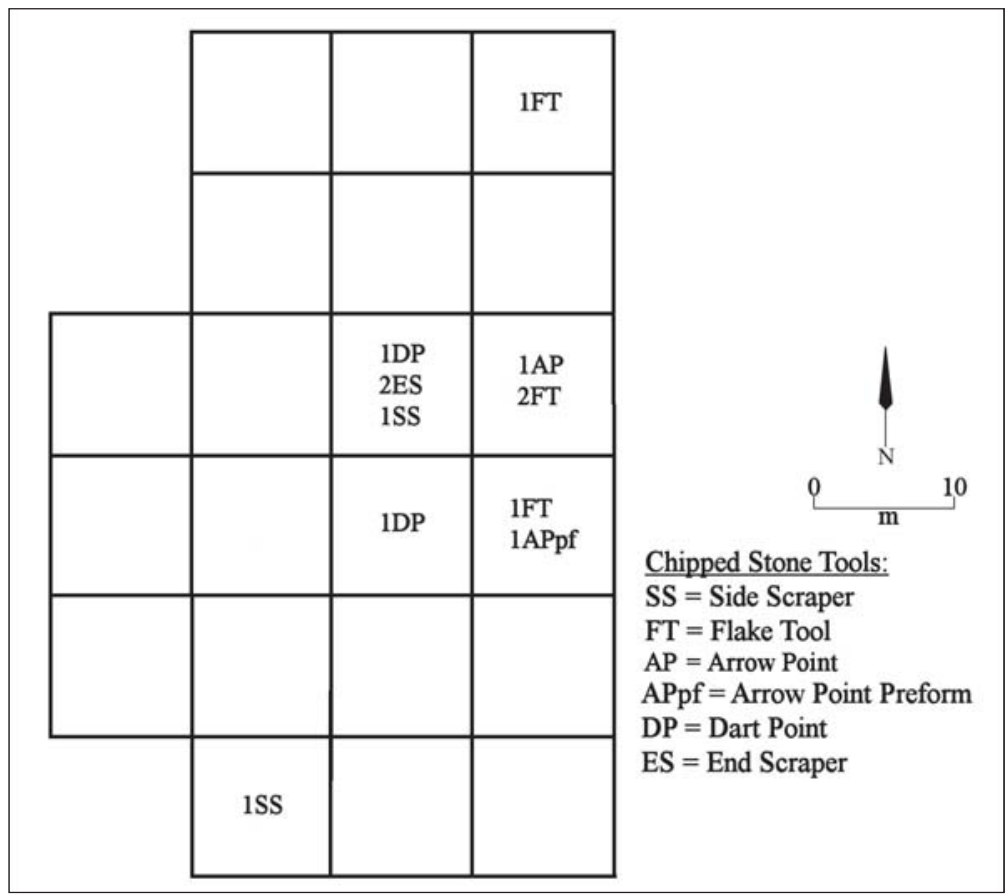

Figure 11. Distribution of chipped stone tools in the surface collection grid.

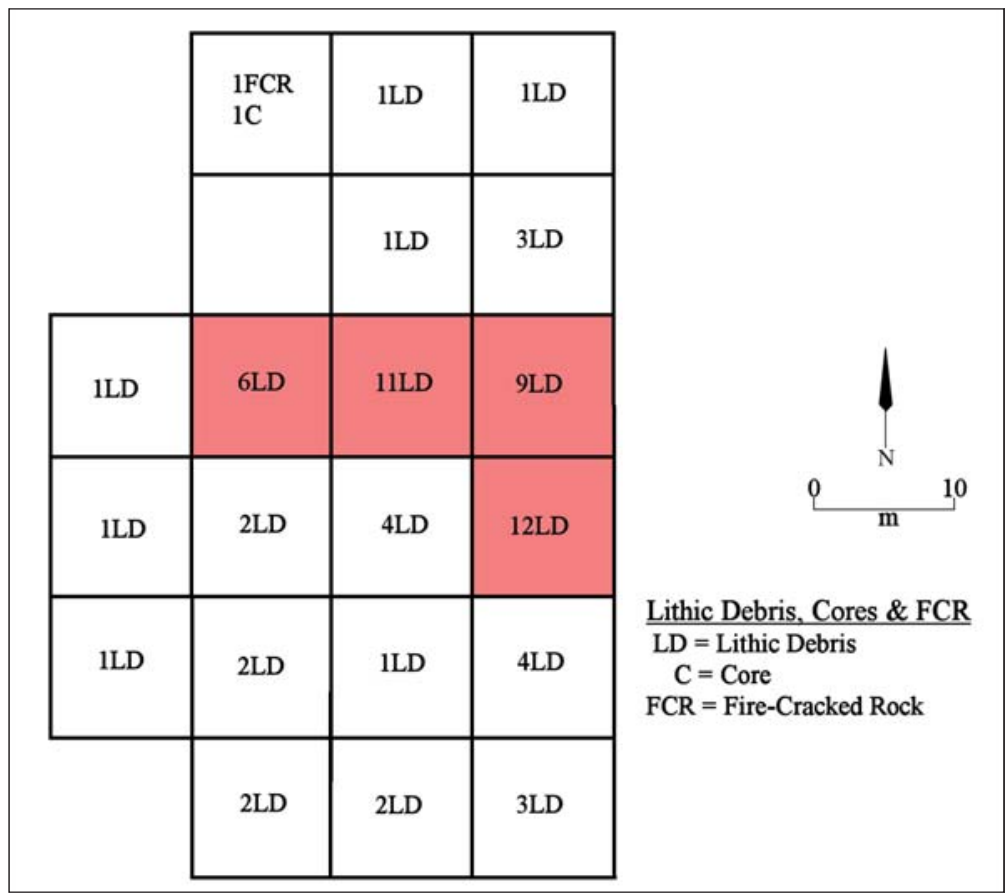

Figure 12. Density of lithic debris, a core fragment, and fire-cracked rock in each 10 x $10 \mathrm{~m}$ collection unit. 
Finally, a small number of mid- $19^{\text {th }}$ to early $20^{\text {th }}$ century historic artifacts $(n=14)$ were recovered from the surface collection grid at the Peach Orchard site (Figure 13). About 71 percent of these artifacts are from the core artifact density of the surface collection grid (see Figure 4), but they are not associated with the ancestral Caddo occupation at the site.

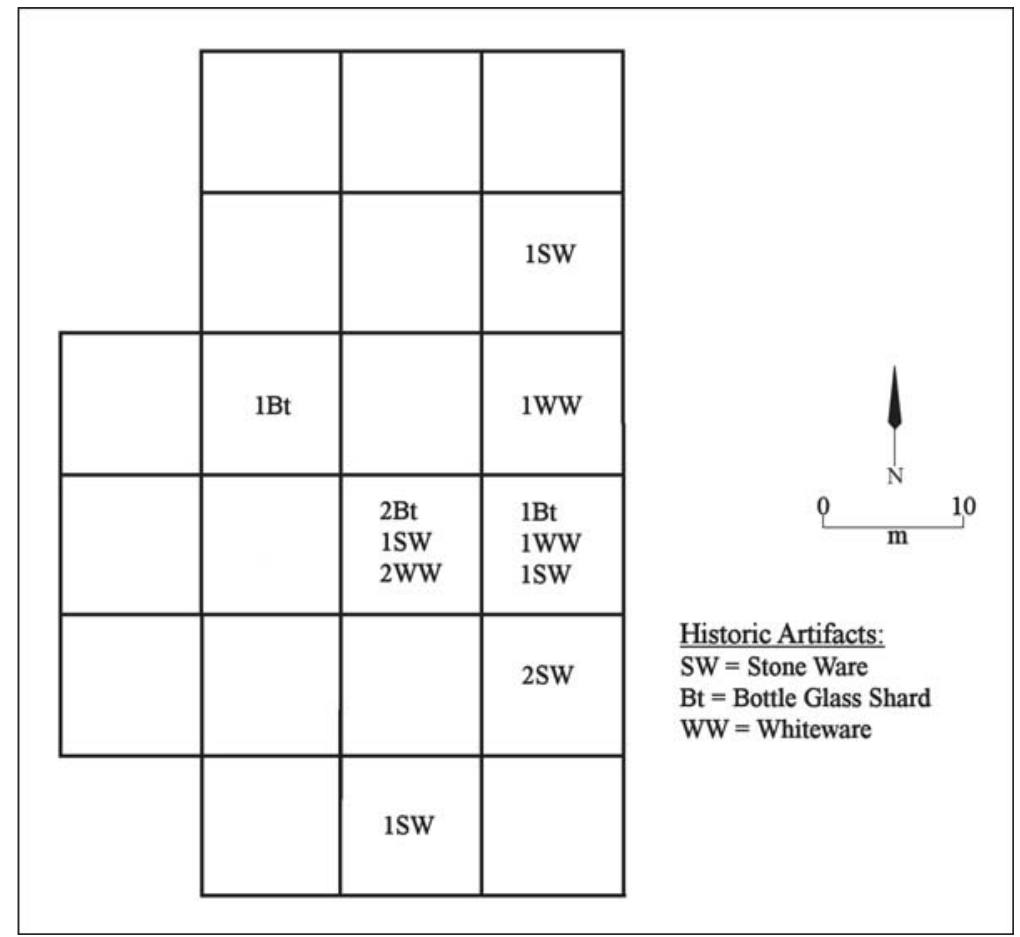

Figure 13 . Density of mid- $19^{\text {th }}$ to early $20^{\text {th }}$ century historic artifacts in each $10 \times 10 \mathrm{~m}$ collection unit.

\section{Artifact Assemblage}

\section{Ceramic Sherds}

A total of 2102 ceramic vessel sherds are in the surface-collected artifact assemblage. These sherds are from plain, utility, and fine ware vessels, tempered almost exclusively with grog (Table 1). The utility ware sherds comprise about 65 percent of the sherds, the plain ware sherds represent 29 percent of the assemblage, and the remaining 6 percent of the sherds are from fine ware vessels. Only 1.4 percent of the sherds are from bone-tempered vessels, and the remaining sherds ( 98.6 percent) are from grog-tempered vessels; the highest proportion of bone-tempered sherds is in the plain wares ( 3.3 percent) and the fine wares (1.6 percent). The overall low proportion of bone-tempered sherds is consistent with Historic Neche cluster assemblages in the Neches River basin (Perttula 2016:Table 3, this volume).

Table 1. Ceramic wares at the Peach Orchard site.

\begin{tabular}{llll}
\hline Ceramic Ware & Grog-tempered & Bone-tempered & $\mathrm{N}$ \\
\hline Plain & 586 & 20 & 606 \\
Utility & 1360 & 7 & 1367 \\
Fine & 127 & 2 & 129 \\
\hline Totals & 2073 & 29 & 2102 \\
\hline
\end{tabular}


The utility wares from the Peach Orchard site are dominated by sherds from vessels with brushing marks on the rim and body (Table 2); based on the 10+ mm thickness of many of the body sherds, the brushed vessels were large jars with a 4-5+ gallon holding capacity. The sherds with just brushed decorative elements $(n=1206)$ comprise more than 80 percent of all the decorated sherds in the assemblage, and more than 88 percent of the utility ware sherds. These sherds are from Bullard Brushed jars with horizontal brushing on the rim and primarily vertical brushing on the vessel bodies; about 1 percent of the brushing on vessel bodies had either opposed or overlapping brushing marks.

Table 2. Decorative methods and elements in the utility ware sherds from the Peach Orchard site.

\begin{tabular}{llll}
\hline Decorative method/element & Rim & Body & N \\
\hline $\begin{array}{l}\text { Appliqued } \\
\text { parallel appliqued ridges }\end{array}$ & - & 2 & 2 \\
& & & \\
Brushed & 10 & - & 10 \\
horizontal brushed & - & 8 & 8 \\
opposed brushed & - & 3 & 3 \\
overlapping brushed & - & 1185 & 1185 \\
parallel brushed & & &
\end{tabular}

\section{Brushed-Appliqued}

parallel brushed and straight appliqued ridge

\section{Brushed-Incised}

opposed incised lines and opposed brushed parallel brushed-incised marks and lines parallel brushed and overlying opposed incised lines (Spradley Brushed-Incised) parallel brushed and overlying intersecting lines (Spradley Brushed-Incised)

parallel brushed and overlying parallel lines

(Spradley Brushed-Incised)

parallel brushed and overlying straight line

straight incised line and diagonal opposed

brushed

\section{Brushed-Pinched}

parallel brushed and pinched ridge through the brushing

\section{Brushed-Punctated}

diagonal brushed and adjacent linear tool punctated row

horizontal brushed and tool punctated row under lip

parallel brushed with circular punctated row through the brushing

parallel brushed with tool punctated row through the brushing parallel brushed adjacent to tool punctated row parallel brushed between tool punctated rows 
Table 2. Decorative methods and elements in the utility ware sherds from the Peach Orchard site, cont.

\begin{tabular}{|c|c|c|c|}
\hline Decorative method/element & Rim & Body & $\mathrm{N}$ \\
\hline \multicolumn{4}{|l|}{ Grooved } \\
\hline horizontal grooved & 2 & - & 2 \\
\hline parallel grooved & - & 11 & 11 \\
\hline straight groove & - & 7 & 7 \\
\hline \multicolumn{4}{|l|}{ Grooved-Incised } \\
\hline straight groove and diagonal incised line & - & 1 & 1 \\
\hline \multicolumn{4}{|l|}{ Grooved-Punctated } \\
\hline $\begin{array}{l}\text { horizontal grooved and tool punctated row } \\
\text { between grooves }\end{array}$ & 1 & - & 1 \\
\hline \multicolumn{4}{|l|}{ Incised } \\
\hline diagonal incised lines & 1 & - & 1 \\
\hline diagonal opposed incised lines & - & 2 & 2 \\
\hline horizontal incised line or lines & 1 & - & 1 \\
\hline opposed incised lines & - & 5 & 5 \\
\hline parallel incised lines & - & 30 & 30 \\
\hline straight incised line & - & 27 & 27 \\
\hline \multicolumn{4}{|l|}{ Incised-Punctated } \\
\hline $\begin{array}{l}\text { parallel incised lines and tool punctates } \\
\text { between lines }\end{array}$ & - & 1 & 1 \\
\hline \multicolumn{4}{|l|}{ Neck Banded } \\
\hline horizontal neck bands & 2 & - & 2 \\
\hline parallel neck bands & - & 1 & 1 \\
\hline \multicolumn{4}{|l|}{ Punctated } \\
\hline circular punctated rows & - & 1 & 1 \\
\hline fingernail punctated rows & - & 1 & 1 \\
\hline single tool punctate & - & 2 & 2 \\
\hline tool punctated row or rows & - & 12 & 12 \\
\hline tool punctated row below lip & 4 & - & 4 \\
\hline Totals & 22 & 1345 & 1367 \\
\hline
\end{tabular}

Another 42 sherds (3.1 percent of the utility wares) have brushing elements in association with either appliqued ridges, incised lines, pinching, or punctations. Those sherds $(n=10)$ with parallel brushing marks and overlying opposed incised lines, parallel brushing and overlying intersecting lines, and parallel brushing marks and overlying parallel lines are from Spradley Brushed-Incised jars. This type is found on Historic Caddo Allen phase sites in the Neches-Angelina river basins in East Texas. It consists of parallel brushing elements with overlapping straight incised lines that are opposed or perpendicular to the brushing (Marceaux 2011:140 and Figure 5.2).

Other utility wares in the Peach Orchard ceramic assemblage include Bullard Brushed jar sherds $(n=17)$ with tool punctated rows pushed through the brushing marks on either the rim or the vessel body, 
as well as Maydelle Incised jar sherds with diagonal or diagonal opposed incised lines on the vessel rim (see Table 2). There are also 22 sherds from Lindsey Grooved jars. Lindsey Grooved is an Allen phase utility ware type comprised of large bowls or jars with direct or slightly everted rims. The rims have shallow horizontal grooves. Lindsey Grooved vessels also occur in conjunction with appliqued, brushed, incised, or punctated elements, as they do in the Peach Orchard assemblage (see Table 2), typically either at the rim-body juncture or on the vessel body.

Three rim or body sherds are from La Rue Neck Banded jars (see Table 2). This utility ware is present in both Late Caddo Frankston phase (ca. A.D. 1400-1680) and Historic Caddo Allen phase components in the Neches and Angelina River basins.

Sherds from vessels decorated with circular, fingernail, or tool punctations comprise 1.5 percent of the utility wares from the Peach Orchard site (see Table 2 ). There are currently no defined punctated utility ware types in the Neches River basin.

About 60 percent of the fine ware sherds are from Patton Engraved vessels (Table 3 and Figure 14ak), the key ceramic type found in Historic Caddo sites in the Neches and Angelina river basins. The rim sherds with a horizontal engraved line beneath the lip that has tick marks $(n=7)$, as well as body sherds $(n=62)$ with rows of tick marks and/or parallel or straight engraved lines with small pendant triangles or tick marks, are likely from Patton Engraved, var. Allen vessels (Perttula 2011:Figure 6-66a) or Patton Engraved, var. Fair vessels with widely-spaced horizontal engraved lines with tick marks (Perttula 2011:Figure 6-66d). The sherds with curvilinear or circular elements $(n=8)$ and tick marks are from Patton Engraved, var. Freeman and var. Fair vessels; the circles with tick marks are a characteristic decorative element on Patton Engraved, var. Fair vessels (Perttula 2011:Figure 6-66c-d).

Table 3. Decorative methods and elements in the fine ware sherds from the Peach Orchard site.

\begin{tabular}{|c|c|c|c|}
\hline Decorative method/element & Rim & Body & $\mathrm{N}$ \\
\hline \multicolumn{4}{|l|}{ Engraved } \\
\hline $\begin{array}{l}\text { circular engraved el. with triangular tick marks } \\
\text { (Patton Engraved) }\end{array}$ & - & 2 & 2 \\
\hline $\begin{array}{l}\text { curvilinear engraved line or lines with triangular } \\
\text { tick marks (Patton Engraved) }\end{array}$ & - & 4 & 4 \\
\hline $\begin{array}{l}\text { curvilinear engraved line with triangular tick } \\
\text { marks and diagonal opposed engraved lines } \\
\text { (Patton Engraved) }\end{array}$ & - & 2 & 2 \\
\hline $\begin{array}{l}\text { horizontal engraved line with triangular tick } \\
\text { marks below lip (Patton Engraved) }\end{array}$ & 7 & - & 7 \\
\hline row of linear tick marks (Patton Engraved) & - & 2 & 2 \\
\hline $\begin{array}{l}\text { parallel engraved lines with triangular tick marks } \\
\text { (Patton Engraved) }\end{array}$ & - & 10 & 10 \\
\hline parallel engraved lines, one line with tick marks & - & 7 & 7 \\
\hline row of linear tick marks (Patton Engraved) & - & 1 & 1 \\
\hline $\begin{array}{l}\text { straight engraved line with triangular tick marks } \\
\text { (Patton Engraved) }\end{array}$ & - & $37 *$ & 37 \\
\hline $\begin{array}{l}\text { straight row of triangular tick marks } \\
\text { (Patton Engraved) }\end{array}$ & - & 5 & 5 \\
\hline cross-hatched engraved zone (King Engraved) & - & 1 & 1 \\
\hline curvilinear engraved lines & - & 1 & 1 \\
\hline curvilinear hatched zone & - & 1 & 1 \\
\hline diagonal hatched zone & - & 1 & 1 \\
\hline
\end{tabular}


Table 3. Decorative methods and elements in the fine ware sherds from the Peach Orchard site, cont.

\begin{tabular}{|c|c|c|c|}
\hline Decorative method/element & Rim & Body & $\mathrm{N}$ \\
\hline \multicolumn{4}{|l|}{ Engraved, cont. } \\
\hline diagonal opposed engraved lines & - & 1 & 1 \\
\hline horizontal engraved line below lip & 3 & - & 3 \\
\hline horizontal and diagonal engraved lines & 1 & 1 & 2 \\
\hline opposed engraved lines & - & 7 & 7 \\
\hline parallel engraved lines & - & 11 & 11 \\
\hline rectilinear engraved lines & - & 4 & 4 \\
\hline rectilinear hatched zone & - & 2 & 2 \\
\hline straight engraved line & - & 14 & 14 \\
\hline $\begin{array}{l}\text { triangular-shaped zone with diagonal hatched } \\
\text { lines (Poynor Engraved) }\end{array}$ & - & 1 & 1 \\
\hline \multicolumn{4}{|l|}{ Engraved-Brushed } \\
\hline $\begin{array}{l}\text { diagonal line and diagonal cross-hatched } \\
\text { zone and horizontal brushed on body } \\
\text { (King Engraved) }\end{array}$ & - & 1 & 1 \\
\hline $\begin{array}{l}\text { horizontal-diagonal engraved lines and diagonal } \\
\text { brushed body }\end{array}$ & - & 1 & 1 \\
\hline \multicolumn{4}{|l|}{ Trailed } \\
\hline curvilinear trailed lines & - & 1 & 1 \\
\hline Totals & 11 & 118 & 129 \\
\hline
\end{tabular}

*two sherds with a white pigment in tick marks

King Engraved is an Allen phase fine ware found in ceramic assemblages in the Neches and Angelina river basins; two sherds of the type are in the Peach Orchard assemblage (Figure 15a, g), and one carinated bowl sherd has a horizontal brushed body. Decorative elements include cross-hatched engraved zones, either in panels, in panel dividers, or in large bands oriented in several directions on the rim (Marceaux 2011:154); another engraved sherd has a horizontal-diagonal engraved element on the rim panel of a carinated bowl and diagonal brushing marks on the vessel body. The four body sherds with rectilinear engraved elements (Figure 15d) may be from Mayhew Rectilinear. This new type is described by Jackson et al. (2012:178 and Figures 3-58 and 4-8) from the Mayhew site (41NA21) and the Gallant Falls site (41NA344), an Allen phase component and an early $18^{\text {th }}$ century Spanish mission, respectively, in the Angelina River basin. Sherds of this type have engraved or trailed rectilinear or curved lines; some sherds of the type have tick marks.

Several engraved sherds have hatched zones, either rectilinear or curvilinear in shape (see Figure 15b-c, e); these may be from unrecognized regional varieties of Poynor Engraved (see Perttula 2011:Figure 6-65). Another engraved sherd has a triangular-shaped zone filled with diagonal hatched lines (see Figure 15f), and this is a distinctive element on several defined varieties of Poynor Engraved (Perttula 2011:Figure 6-64). Finally, one Keno Trailed sherd, likely from a bowl, with curvilinear trailed lines is in the Peach Orchard fine ware assemblage (see Table 3).

\section{Ceramic Pipe Sherds, Burned Clay, and Clay Coil}

The first ceramic pipe sherd (Surface Collection Unit 9) is an undecorated grog-tempered rim sherd from an elbow pipe; the rim is $3.9 \mathrm{~mm}$ thick. The second grog-tempered elbow pipe sherd (from Unit 


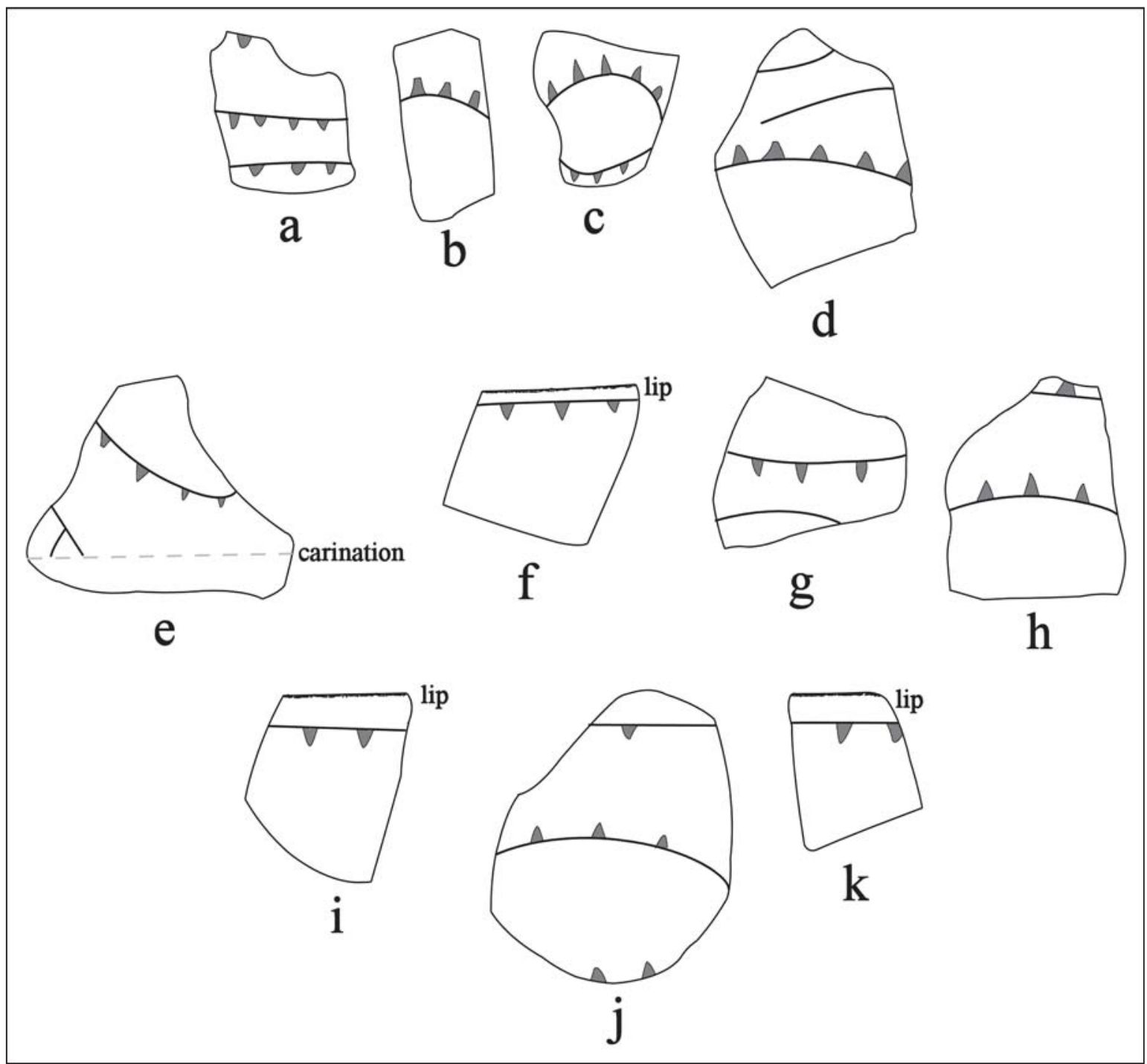

Figure 14. Decorative elements on Patton Engraved rim and body sherds from the Peach Orchard site: a-b, Unit 2; c, Unit 5; d, Unit 6; e-f, Unit 8; g, Unit 9; h. Unit 10; i, Unit 12; j, Unit 14; k, Unit 20.

13) is part of the distal knob of the basal stem; there are two horizontal incised lines on the stem. This pipe is either a Var. B or Var. C elbow pipe style that has been defined in the Neches River basin (Perttula 2011:Figure 6-23). The two burned clay pieces may represent remnants of a hearth or earth oven, while the clay coil fragment $(36.0 \mathrm{~mm}$ in length and $16.9 \mathrm{~mm}$ in diameter) is the burned residue of pottery manufacture at the site.

\section{Chipped Stone Tools}

The surface-collected assemblage of chipped tools includes two dart point fragments, an arrow point fragment and an ovoid arrow point preform, three flake tools, two end scrapers, and two side scrapers (Table 4).The chipped stone tools are from two different components: the earliest component is marked by two dart points, likely of Woodland period age, and the remaining 10 chipped stone tools (arrow points, flake tools, and scrapers) are associated with the Historic Caddo Allen phase component. 


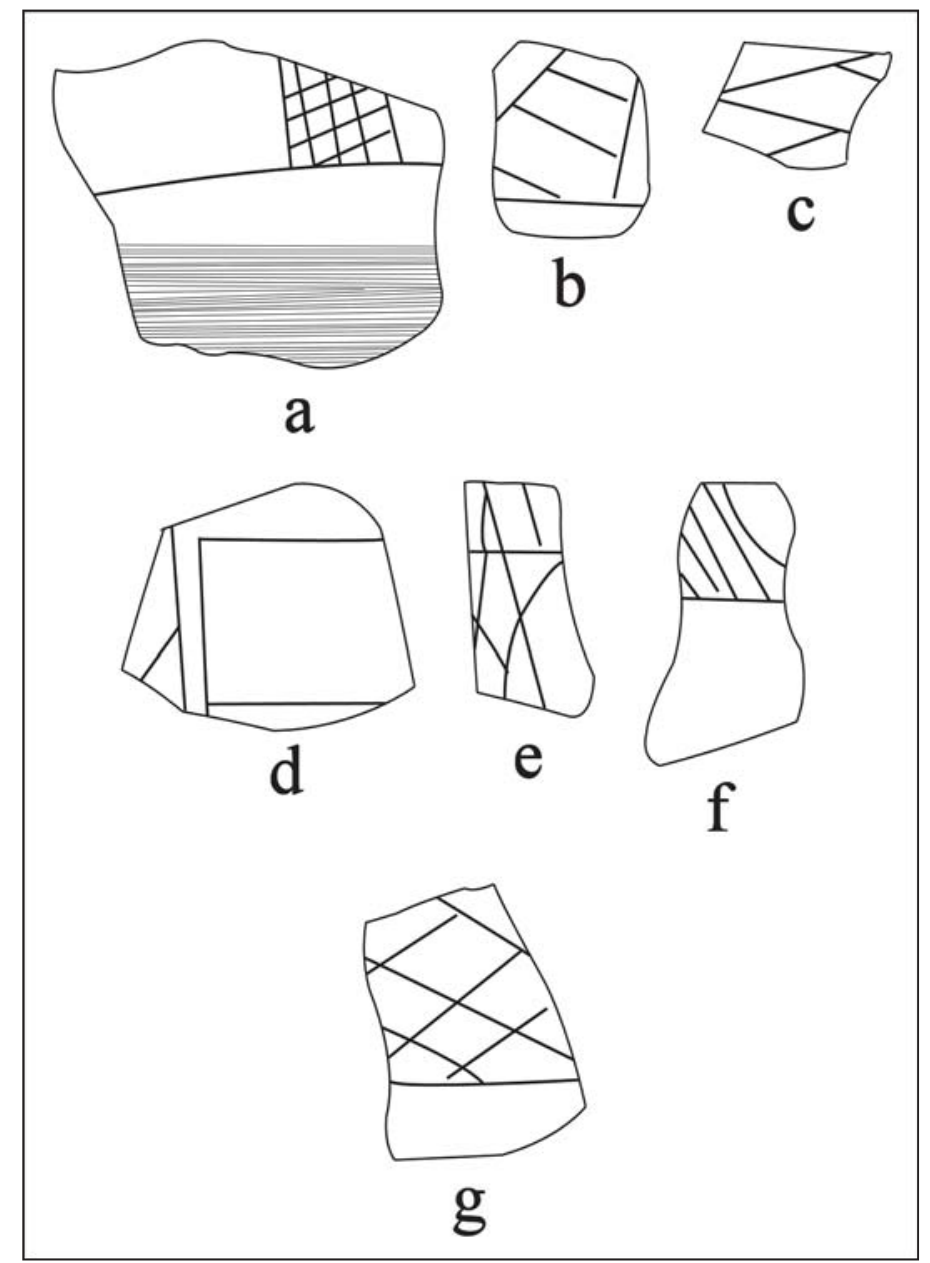

Figure 15. Other decorative elements on selected engraved fine ware sherds from the Peach Orchard site: a, Unit 5; b, Unit 7; c, Unit 11; d, Unit 12; e, Unit 16; f, Unit 18; g, Unit 19.

Table 4. Chipped Stone Tools from the Peach Orchard site.

\begin{tabular}{lll}
\hline Surface Collection Unit & Tool Type & Lithic Raw Material \\
\hline Unit 3 & side scraper & dark gray chert \\
Unit 8 & bilateral flake tool & very dark gray chert \\
& ovoid arrow point preform & brownish-gray chert \\
dart point tip & petrified wood \\
Unit 9 & arrow point tip & light gray-gray chert \\
Unit 12 & unilateral flake tool & honey-colored chert \\
& unilateral flake tool & light-dark gray chert \\
dart point stem & gray novaculite \\
Unit 13 & end scraper & very dark gray chert \\
& end scraper fragment & dark brown chert \\
& side scraper & very dark gray chert \\
unilateral flake tool 19 & & black-gray chert \\
\hline
\end{tabular}

One of the dart points was made with a locally available petrified wood, while the other-the stem to a Woodland period Gary point - was made from a non-local gray novaculite. The nearest source for such raw material would be the gravels of the Red River, well to the north of the site. 
The chipped stone tools likely associated with the Allen phase component at the Peach Orchard site are all made from non-local cherts (see Table 4), probably obtained from Central Texas Edwards Plateau chert sources, or perhaps as gravels in the Neches River (cf. Girard 1995). The honey-colored chert or "beeswax" chert is a distinctive Edwards Plateau raw material (Miller 2008:27).

The one arrow point tip in Unit 12 is unifacial with a serrated edge; the blade is $4.4 \mathrm{~mm}$ thick. The arrow point preform from Unit 8 is ovoid in shape and unifacially flaked.

The four flake tools are expedient tools, "flake/blade blanks that have not been altered prior to their use in the performance of a task (e.g., the use of an unmodified flake as a knive or scraper)" (Tomka 2001:209). Each of these tools has evidence in the form of micro-flaking from tool use, on either one $(n=3)$ or two $(n=1)$ edges. Utilized edges range from 11.2-21.0+ mm in length.

Formally-hafted scrapers are relatively common tools on Allen phase sites (Perttula et al. 2010:39), as they are at the Peach Orchard site, suggesting that the butchering and processing of large game animals was an important activity during the Historic Caddo occupation. The generally small size of the end $(n=2)$ and side $(n=2)$ scrapers also suggests that the focus of Caddo butchering and processing activities was on medium-sized prey that was being hunted, such as deer.

\section{Lithic Debris, Core Fragment, and Fire-Cracked Rock}

The lithic debris from the surface-collected units at the Peach Orchard site includes various colors of chert ( $n=25,37$ percent of the assemblage), single pieces of novaculite and Manning Fused glass ( $n=2$, 3 percent), and local petrified wood, quartzite, and quartz raw materials ( $\mathrm{n}=40,60$ percent) (Table 5). The chert raw materials are from non-local sources, obtained perhaps from chert sources in the Edwards Plateau, while the novaculite sources are in the Ouachita Mountains of southeastern Oklahoma and southwestern Arkansas, but this material can be found in Red River stream gravels. The Manning Fused Glass is a distinctive fused volcanic glass found in the Manning Formation in East and Southeast Texas (Brown 1976:Figure 3), about $80 \mathrm{~km}$ from the Peach Orchard site. A number of ancestral Caddo sites in East Texas have tools and lithic debris of Manning Fused Glass (Brown 1976:196-199), including the Allen phase component at the Deshazo site (41NA27) in the Angelina River basin.

Table 5. Lithic Debris from the Peach Orchard site.

\begin{tabular}{llll}
\hline Raw Material & Cortical pieces & Non-cortical pieces & N \\
\hline bluish-gray chert & 1 & - & 1 \\
brownish-gray chert & 1 & 1 & 2 \\
dark gray chert & - & 5 & 5 \\
light gray chert & 2 & 3 & 5 \\
light gray-gray chert & - & 1 & 1 \\
gray chert & 2 & 3 & 5 \\
gray-dark gray chert & 1 & - & 1 \\
gray-very dark gray chert & - & 1 & 1 \\
light gray-dark gray chert & - & 1 & 1 \\
dark gray chert & - & 1 & 1 \\
very dark gray chert & - & 1 & 1 \\
very dark grayish-brown chert & 1 & - & 1 \\
Chert, Subtotal & & & 25
\end{tabular}


Table 5. Lithic Debris from the Peach Orchard site, cont.

\begin{tabular}{llll}
\hline Raw Material & Cortical pieces & Non-cortical pieces & $\mathrm{N}$ \\
\hline white novaculite & - & 1 & 1 \\
Manning Fused Glass & - & 1 & 1 \\
petrified wood & 20 & 15 & 35 \\
quartzite & 3 & 1 & 4 \\
quartz & 1 & - & 1 \\
Subtotal & 24 & 16 & 40 \\
\hline Totals & 32 & 35 & 67 \\
\hline
\end{tabular}

The single core fragment and one piece of ferruginous sandstone fire-cracked rock were both collected from Surface Collection Unit 21 (see Figure 12). The core fragment is on a cortical piece of petrified wood.

\section{Animal Bones}

A few pieces of animal bone were recovered from the surface collection grid at the Peach Orchard site. This includes one unburned bone in Surface Collection Unit 8, two unburned bones in Surface Collection Unit 9, and a single burned bone in Surface Collection Unit 14. The bones are distributed within the core artifact density of the surface collection grid (see Figure 4), and are likely associated with the ancestral Caddo occupation at the site.

\section{Mid-19 ${ }^{\text {th }}$ to Early $20^{\text {th }}$ Century Historic Artifacts}

The 14 historic artifacts recovered from the surface collection grid at the Peach Orchard site include stoneware sherds $(n=6)$, plain and decorated whiteware sherds $(n=4)$, and bottle glass sherds $(n=4)$ (Table $6)$. The few mid- $19^{\text {th }}$ century historic materials in the collection are represented by the one annular slipbanded whiteware sherd from Surface Collection Unit 8 and the four sherds of dark green and green bottle glass from intoxicant containers (wine, whiskey, or brandy).

Table 6. Historic artifacts recovered in the surface collection grid at the Peach Orchard site.

\begin{tabular}{lll}
\hline Collection Unit & Artifact Category & $\mathrm{N}$ \\
\hline Unit 3 & Bristol-glazed stoneware body sherd & 1 \\
Unit 4 & Bristol-glazed stoneware body sherd & 2 \\
Unit 8 & dark green bottle glass sherd & 1 \\
& brown-white-black annular whiteware sherd & 1 \\
int./ext. brown lead-glazed stoneware body sherd & 1 \\
Unit 9 & plain whiteware sherd & 2 \\
& Bristol-glazed stoneware body sherd & 1 \\
& dark green bottle glass sherd & 1 \\
Unit 12 & green bottle glass sherd & 1 \\
Unit 14 & plain whiteware body sherd & 1 \\
Unit 16 & dark green bottle glass sherd & 1 \\
\hline
\end{tabular}


The one interior/exterior brown lead-glazed stoneware sherd is from a vessel that was likely made between ca. 1870-1900 (Greer 1981). The Bristol-glazed stoneware became popular around the turn of the $20^{\text {th }}$ century (Greer 1981).

\section{Isolated Dart Point Find}

A single isolated dart point was recovered on the surface of the landform, ca. 70-100 m north of the northern part of the surface collection grid. The point compares favorably in stem and base shape, as well as its small downward-pointing barbs, to the Bulverde point. This point type may date from ca. 35004400 years B.P. - at least in Central Texas (see Collins et al. 2011) - in the earlier part of the Late Archaic in East Texas. The point is made from a non-local brownish-gray chert, and is $57.0+\mathrm{mm}$ in length, $33.8 \mathrm{~mm}$ in width, $6.0 \mathrm{~mm}$ thick, and has an $18.8 \mathrm{~mm}$ stem width.

\section{Summary and Conclusions}

In November and December 2015, a controlled surface collection of 2100 square meters of a shallowly plowed field was conducted at the Peach Orchard site (41CE477). This is one of a number of associated Historic Allen phase components on Bowles Creek, a southward-flowing tributary to the Neches River. During the course of the surface collection, more than 2100 ancestral Caddo sherds were collection from $2110 \times 10 \mathrm{~m}$ grid units, along with two ceramic elbow pipe sherds, 12 chipped stone tools (including one Woodland period dart point fragment), 67 pieces of lithic debris and a core fragment, as well as a small amount of mid- $19^{\text {th }}$ to early $20^{\text {th }}$ century artifacts (i.e., stoneware and whiteware sherds and bottle glass sherds); no European trade goods were recovered in the controlled surface collection. The Caddo cultural materials occur throughout the 2100 square meter collection area, but the core area with the highest densities of artifacts covers a 700 square meter area in the central part of the site. It is suspected that this core spatial area likely represents one or two contemporaneous Historic Caddo households and outdoor activity areas, but associated trash midden deposits have not yet been identified at the Peach Orchard site.

The ceramic vessel sherd assemblage from the Peach Orchard site is represented almost exclusively by grog-tempered plain, utility, and fine ware vessels. Of the almost 1500 decorated sherds from the surface collection units, utility ware sherds from Bullard Brushed vessels account for more than 83 percent of the decorated sherds, and other utility wares include low proportions of sherds from Maydelle Incised, La Rue Neck Banded, Lindsey Grooved, and Spradley Brushed-Incised vessels. The fine wares from the Peach Orchard site are dominated by sherds from several varieties of Patton Engraved vessels, a few sherds of King Engraved and Mayhew Rectilinear, one Poynor Engraved sherd, as well as one Keno Trailed bowl sherd.

The identified ceramic types in the different Neche cluster sites form a consistent Allen phase set in both Group I and Group IIA-B assemblages, as they are dominated by sherds from Bullard Brushed and Patton Engraved vessels (Table 7). The Peach Orchard site is included in Group I of the Neche Cluster of sites. Also ubiquitous in the Group I and IIA assemblages are sherds from Lindsey Grooved vessels. Poynor Engraved sherds are present in low numbers in Group I and IIA assemblages, as are La Rue Neck Banded sherds, while King Engraved sherds are present in only the Group I and IIA assemblages on Bowles Creek. Maydelle Incised and Killough Pinched types are identified in assemblages of all three groups, while Spradley Brushed-Incised sherds have been identified in two Group I and IIA sherd assemblages (Table 7). 
Table 7. Identified ceramic types in the Neche cluster sites.

\begin{tabular}{|c|c|c|c|c|c|c|c|c|c|}
\hline Site & PA & $\mathrm{KE}$ & $\mathrm{PO}$ & LG & LNB & MI & $\mathrm{BB}$ & KP & SBI \\
\hline \multicolumn{10}{|l|}{ Group I } \\
\hline 41CE293 & & + & + & + & + & & + & & \\
\hline 41CE474 & + & & + & + & & & + & & \\
\hline 41CE477 & + & + & + & + & + & + & + & & + \\
\hline \multicolumn{10}{|c|}{ Group IIA } \\
\hline 41CE48 & + & & & & + & & + & & \\
\hline 41CE475 & + & & + & + & & + & + & + & + \\
\hline 41CE20 & + & & + & & + & + & + & & \\
\hline 41CE476 & + & + & & + & & & + & & \\
\hline \multicolumn{10}{|c|}{ Group IIB } \\
\hline 41CE291 & + & & & & & + & + & & \\
\hline
\end{tabular}

+=presence; $\mathrm{PA}=$ Patton Engraved; KE=King Engraved; $\mathrm{PO}=$ Poynor Engraved; LNB=La Rue Neck Banded; MI=Maydelle Incised; $\mathrm{BB}=$ Bullard Brushed; KP=Killough Pinched; SBI=Spradley Brushed-Incised

The Neche cluster of ceramic vessel sherd assemblages includes several Allen phase Historic Caddo sites on Bowles Creek and the Neches River (41CE291). These components have high proportions of brushed sherds and high ratios of brushed sherds to other wet paste sherds (Table 8). These assemblages are also almost exclusively comprised of grog-tempered vessels, but differences between the sites in the proportion of bone-tempered vessels (either as the sole temper or in combination with grog) suggest that two contemporaneous groups of Allen phase sites are present in the Neche cluster that had different ceramic technological practices. These two groups (I and IIA) also are notably different in brushed to plain sherd ratios when compared to the ceramic sherd assemblage at 41CE291 (Table 8), where there are many punctated sherds relative to brushed sherds in the assemblage.

Table 7. Ceramic sherd assemblage comparisons of Neche cluster sites.

\begin{tabular}{llllll}
\hline Site & \% Grog & \% Bone & P/DR & B/Pl & B/OWP*** \\
\hline $\begin{array}{l}\text { Allen phase } \\
\text { Group I }\end{array}$ & & & & & \\
41 CE293 & $98.1^{* *}$ & $5.6^{* *}$ & 0.12 & 7.50 & 5.70 \\
41 CE474 & 97.1 & 2.9 & 0.30 & 3.08 & 9.25 \\
41CE477* & 98.5 & 1.5 & 0.40 & 2.11 & 7.88 \\
Group IIA & & & & & \\
41CE48 & 84.2 & 27.7 & 0.31 & 2.43 & 5.48 \\
41CE475 & 91.2 & 9.2 & 0.34 & 2.55 & 11.3 \\
41CE20 & 98.4 & 14.3 & 0.40 & 2.07 & 5.0 \\
41CE476 & 91.2 & 9.2 & 0.45 & 1.77 & 7.0 \\
Group IIB & & & & & \\
41CE291 & 97.4 & 2.6 & 0.30 & 1.94 & 1.84 \\
\hline
\end{tabular}

$\mathrm{P} / \mathrm{DR}=$ plain/decorated sherd ratio; B/Pl-brushed/plain sherd ratio; B/OWP=brushed/other wet paste (i.e., incised, appliqued, punctated, etc.) sherd ratio

*includes the sample of 71 sherds discussed in Perttula et al. (2016) and the sample discussed in this article.

**percentages will total to more than 100 percent because some sherds have more than one kind of temper

***sherds with multiple decorative elements (i.e., brushed-incised or brushed-punctated, etc.) are counted as both brushed and as other wet paste sherds 
In conclusion, the ancestral Caddo sherd collection from the Peach Orchard site strongly suggests that it was the location of a post-A.D. 1680 Historic Caddo settlement, probably a settlement by the Neche or Nechas Caddo peoples. Patton Engraved sherds, the principal Allen phase fine ware ceramic type in the Neches River basin, are common in the Peach Orchard site assemblage, and other aspects of the ceramic assemblage are consistent with Neche cluster sites. Perhaps the Peach Orchard site is one of the settlements occupied by a Neches or Nechas Caddo group around the time of the late $17^{\text {th }}$-early $18^{\text {th }}$ century Spanish colonization of the middle reaches of the Neches River, but before sustained French trading activities, when several missions were established in this general locale: Mission San Francisco de los Tejas (1690-1693), Mission El Santisimo de Nombre Maria (1690-1692), and Mission Nuestra Padre de San Francisco de Tejas or los Nechas (1716-1719, 1721-1730).

\section{Acknowledgments}

Lance Trask prepared Figures 3-15 in this article; Figures 1 and 2 were prepared by Kevin Stingley. We also thank Lonnie Lindsey for permission to conduct the controlled surface collection at the Peach Orchard site.

\section{References Cited}

Brown, K. M.

1976 Fused Volcanic Glass from the Manning Formation. Bulletin of the Texas Archeological Society 47:189207.

Collins, M. B., D. M. Yelacic, and C. B. Bousman

2011 "Realms," A Look at Paleoclimate and Projectile Points in Texas. Bulletin of the Texas Archeological Society 82:3-30.

Girard, J. S.

1995 The Chipped Stone Collection: Technological, Functional, and Typological Analyses. In The Deshazo Site, Nacogdoches County, Texas, Volume 2: Artifacts of Native Manufacture, edited by D. A. Story, pp. 33-156. Studies in Archeology 21. Texas Archeological Research Laboratory, The University of Texas at Austin.

Greer, G. H.

1981 American Stoneware: The Art and Craft of Utilitarian Pottery. Schiffer Publishing Ltd., Exton, Pennsylvania.

Hunter, R. and G. L. Miller

2009 Suitable for Framing: Decorated Shell-Edge Earthenware. Early American Life, August 2009, pp. 8-19.

Jackson, M. K., T. Middlebrook, G. Avery, H. Shafer, and B. Meissner

2012 Trade and Cultural Interaction along El Camino Real de los Tejas During the Spanish Colonial and Republic Periods in Nacogdoches County, Texas. 2 Vols. Nine Flags Museum, Nacogdoches.

Marceaux, P. S.

2011 The Archaeology and Ethnohistory of the Hasinai Caddo: Material Culture and the Course of European Contact. Ph.D. dissertation, Department of Anthropology, The University of Texas at Austin.

Miller, K. A.

2008 A Study of Prehistoric Biface caches from Texas. La Tierra 34(1\&2):1-88. 
Perttula, T. K.

2011 The Ceramic Artifacts from the Lang Pasture Site (41AN38) and the Place of the Site within an Upper Neches River Basin Caddo Ceramic Tradition. In Archeological Investigations at the Lang Pasture Site (41AN38) in the Upper Neches River Basin of East Texas, assembled and edited by T. K. Perttula, D. B. Kelley, and R. A. Ricklis, pp. 145-320. Archeological Studies Program Report No. 129, Texas Department of Transportation, Environmental Affairs Division, Austin.

2016 Utility Ware Ceramic Metrics and Hasinai Caddo Archaeology in East Texas. Journal of Northeast Texas Archaeology 70, this volume.

Perttula, T. K., L. L. Bush, L. Schniebs, T. Middlebrook, and P. S. Marceaux

2010 An Early Historic Caddo Farmstead at the Henry M. Site (41NA60) in Nacogdoches County, Texas. Stephen F. Austin State University Press, Nacogdoches.

Perttula, T. K., K. Stingley, and M. Walters

2016 Historic Caddo Archaeological Sites in Cherokee County, Texas. Journal of Northeast Texas Archaeology 65:1-24.

Tomka, S. A.

2001 The Effect of Processing Requirements on Reduction Strategies and Tool Forms; A New Perspective. In Lithic Debitage: Context, Form, Meaning, edited by W. Andrefsky, jr., pp. 207-223. University of Utah Press, Salt Lake City. 